\section{A Estratégia Como Prática em Diferentes Ritmos: um Estudo do Strategizing em Bandas Musicais}

\author{
Marlos Vinícius Oliveira Ramos e Jacquelaine Florindo Borges
}

\section{RESUMO}

Este artigo propõe um diálogo entre a estratégia como prática social e os estudos culturais, especificamente a articulação entre estilos e identidades, a partir da questão: como práticas de estilo moldam o strategizing de bandas musicais? Para tanto, foi realizada uma pesquisa de campo com 11 bandas musicais, orientada pelo método de múltiplos casos e por uma abordagem qualitativa. Os dados foram coletados com a aplicação da técnica de entrevistas com músicos e empresários, da pesquisa documental em websites e da análise de foto/imagem das bandas. Os resultados mostram que as bandas desenvolvem quatro práticas estratégicas centrais: (a) identidade sonora; (b) identidade estética; (c) coletivo de identidades e habilidades dos músicos (formação e composição da banda); e (d) identidade econômica (crescimento e popularização da banda). Essas práticas são conduzidas a partir de rotinas interativas, comportamentais/comunicacionais, procedimentos de aprendizagem e uso de instrumentos de gestão. É no fluxo dessas práticas que se constitui a estratégia artística da banda: um complexo de ações e instrumentos visando reconhecimento artístico e resultados comerciais no contexto cultural da época. A pesquisa mostra que a abordagem cultural do strategizing é um caminho promissor para conectar diferentes níveis de análise e temas de pesquisa ainda pouco presentes nos estudos da estratégia como prática social: práticas culturais de estilo e interações entre identidades individuais e coletivas em organizações e manifestações culturais.

Palavras-chave: Estratégia como prática, Strategizing, Identidade organizacional, Organização musical.

\section{Strategy as Practice in Different Rhythms: A Study of Strategizing in Musical Bands}

\section{ABSTRACT}

This article proposes a dialogue between strategy as a social practice and cultural studies, specifically the articulation between styles and identities, using the following question: how do style practices shape the strategizing of musical bands? In order to achieve such, field research was carried out with 11 musical bands, guided by the method of multiple cases and a qualitative approach. The data were collected through interviews with musicians and managers, documentary research on websites and photo/image analysis of the bands. The results show the bands develop four core strategic practices: (a) sound identity; (b) aesthetic identity; (c) collective identities and abilities of the musicians (formation and composition of the band); and (d) economic identity (growth and popularization of the band). These practices are conducted through interactive, behavioural/communication routines, learning procedures and use of management tools. It is in the flow of these practices that the artistic strategy of the band is formed: a collection of actions and instruments aimed at artistic recognition and business results in the cultural context of the time. The research shows that the cultural approach of strategizing is a promising way to connect different levels of analysis and research themes that are still not common in the studies of strategy as a social practice: cultural practices of style and interactions between individual and collective identities in cultural organizations and manifestations.

Keywords: Strategy as practice. Strategizing. Organizational identity. Musical organization.

Recebido em: 19/09/2018 Revisado em: 05/11/2018 Aprovado em: 28/01/2019

Check for updates

Marlos Vinícius Oliveira Ramos (iD,

Programa de Pós-Graduação em Administração, Universidade Federal de Uberlândia, Brasil

Mestre em Administração,

Universidade Federal de Uberlândia, Brasil

marlosramos@yahoo.com.br

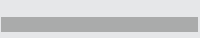

Jacquelaine Florindo Borges (iD,

Programa de Pós-Graduação em Administração, Universidade Federal de Uberlândia, Brasil Doutora em Administração, Universidade de São Paulo, Brasil

jac.borges@uol.com.br 
Introdução

And if I could be who you wanted. If I could be who you wanted. All the time. All the time.

(Fake plastic trees, banda Radiohead)

As bandas musicais são unidades organizacionais compostas por profissionais que produzem arranjos e desenvolvem performances musicais (Murnighan \& Conlon, 1991; Shuker, 1999; Janotti, 2006), são parte da cultura e podem contribuir para o desenvolvimento socioeconômico (Unctad, 2010). Além de um encontro cultural de identidades (Vila, 2012), uma banda realiza um processo de produção de sentido que envolve regras formais e ritualizações partilhadas no decorrer da produção, da expressão e do consumo de gêneros musicais (Born, 2011), assim como de estilos de vida (Featherstone, 1995).

Este artigo propõe um diálogo entre a estratégia como prática social e os estudos culturais, especificamente a articulação entre estilos e identidades, a partir da questão: como práticas de estilo moldam o strategizing de bandas musicais? A pesquisa de campo foi orientada pelo método de múltiplos casos, com uma abordagem qualitativa do material pesquisado. Para a coleta de dados, foram aplicadas as técnicas de entrevistas individuais semiestruturadas com 11 bandas musicais, pesquisa em internet/websites e análise de foto/imagem das bandas.

A música é uma prática cultural humana que se manifesta em diversas atividades sociais: entretenimento, religião, política, educação, entre outros. As práticas musicais se desenvolvem em todos os grupos sociais de formas distintas, de acordo com seus rituais simbólicos e seu conjunto de saberes e crenças (Blacking, 2007). Além de uma prática cultural, a música é um produto da indústria musical (Frith, 1987; Shuker, 1999). Além disso, as organizações musicais, assim como a indústria da música, fazem parte da indústria cultural, composta pelos setores que realizam atividades de criação, produção e comercialização de conteúdo intangível e de natureza cultural (Nakano, 2010). A indústria da música tem uma dimensão global, porém a produção musical afeta as economias locais a partir da geração de emprego e consumo de produtos de música, além de seu impacto em outras atividades econômicas, como: moda, editoras/publicações, turismo. Ainda assim, as bandas musicais são praticamente esquecidas nos estudos acadêmicos de estratégia.

O conceito de strategizing é central nos estudos de estratégia como prática (Golsorkhi, Rouleau, Seidl, \& Vaara, 2010), porém também suscita questionamentos (Carter, Clegg, \& Kornberger, 2008; Ezzamel \& Willmott, 2010) sobre essa prática e o que uma perspectiva pós-moderna ou perspectivas pós-estruturalistas da estratégia podem oferecer ao estudo do strategizing. Tais críticas são dirigidas, sobretudo, à $s-a-p$ ou strategy-as-practice (Jarzabkowski \& Spee, 2009; Whittington, 2003; Whittington \& Melin, 2003; Whittington, Molloy, Mayer, \& Smith, 2006), uma das abordagens dos estudos da estratégia como uma prática social. 


\section{A estratégia como prática: os estrategistas} e a natureza imersa do strategizing

a perspectiva da estratégia como uma prática social, especificamente a abordagem identificada estratégica-como-prática, $s-a-p$ ou strategy-as-practice, tem como objeto de estudo as atividades e os microprocessos, visando explicar a prática que constitui o processo estratégico (Johnson, Melin, \& Whittington, 2003). Estudos da estratégica-como-prática compreendem a estratégia como um fenômeno micro - microatividades; mas também preconizam a necessidade de se articular o nível micro com as influências e os resultados em uma instância macro, tendo em vista a interconectividade existente entre os dois planos (Johnson, Melin, \& Whittington, 2003). Admite-se, ainda, que muito da estrutura social (ferramentas, discursos e tecnologias), por meio da qual é construída a microação, tem propriedades institucionalizadas que permitem sua transmissão dentro e entre os contextos (Jarzabkowski, Balogun, \& Seidl, 2007).

Para os estudos da estratégia-como-prática é essencial a articulação dos níveis micro e macro para se compreender a natureza imersa do "strategizing", ou seja, a forma como as interações localizadas tanto moldam como são moldadas por um contexto mais amplo (Jarzabkowski \& Spee, 2009). Os macrofenômenos estão relacionados a conceitos, ferramentas e estruturação dos elementos que refletem a sociedade e o ambiente de negócios (Wilson \& Jarzabkowski 2004). Os microfenômenos são as interações sociais cotidianas realizadas de forma interpessoal e que podem ser visualizadas como a vida de um processo estratégico (Whittington \& Jarzabkowski, 2004; Wilson \& Jarzabkowski, 2004).

Strategizing refere-se ao fluxo de atividades, ações e interações dos múltiplos atores e as práticas que eles possam realizar no contexto em que se molda a estratégia (Jarzabkowski, Balogun, \& Seidl, 2007; Regnér, 2008). Os praticantes (practioners) são as pessoas que fazem o trabalho de estratégia; as práticas (practices) são as ferramentas sociais, simbólicas e materiais com que a estratégia é feita; e as práxis correspondem ao fluxo de atividade em que a estratégia ficará implícita (Jarzabkowski, Balogun, \& Seidl, 2007; Whittington, 2006). Essa perspectiva da estratégia (Jarzabkowski \& Spee, 2009; Jarzabkowski \& Whittington, 2008) propõe que diversos atores podem ser considerados praticantes/ estrategistas: (i) praticante individual ou grupo de praticantes; e (ii) o praticante dentro de uma organização ou externo a ela, formando uma categoria de profissionais que influencia a estratégia organizacional (consultores, atores institucionais que fazem políticas, tais como, a mídia, os gurus e as escolas de negócio etc.). Isso implica três tipos de praticantes - ator individual interno à organização, conjunto de atores internos à organização e conjunto de atores externos à organização.

As práticas ocorrem em três níveis: micro, meso e macro. As práticas micro da estratégia no nível da experiência individual ou do grupo se referem a um episódio específico, como uma decisão, uma reunião etc. Já no nível meso, os estudos da estratégia analisam as práticas no nível organizacional ou suborganizacional, assim como um programa de mudança, um processo 
estratégico ou um padrão de ações estratégicas. Por fim, no nível de macro práticas, analisa-se as práticas da estratégia em nível institucional, como os padrões de ação de um setor específico do mercado (Jarzabkowski \& Spee, 2009).

A abordagem da $s-a-p$ contribuiu para uma virada rumo à prática nos estudos de estratégia e estabeleceu a centralidade do strategizing para esses estudos (Golsorkhi, Rouleau, Seidl, \& Vaara, 2010). Todavia, essa abordagem tem sido questionada por empregar uma concepção do strategizing com pouca atenção para os seus efeitos no estabelecimento ou transformação das relações sociais (abordagens pós-estruturalista) (Ezzamel \& Willmott, 2010), e também por tentar "acomodar um mix heterogêneo de contribuições" com vieses racionalistas e interpretativistas (Ezzamel \& Willmott, 2010) e vieses da estratégia ortodoxa (Carter, Clegg, \& Kornberger, 2008).

Dentre os estudos que buscam superar estes limites/críticas destacamse aqueles com ênfase na identidade dos praticantes e na natureza performativa da estratégia. Samra-Fredericks (2003) mostra o strategizing como experiência vivida em interações cotidianas, imerso em aspectos morais e emocionais; Jarzabkowski e Spee (2009) analisam a necessidade de se compreender o papel da(s) identidades(s) dos diferentes níveis da prática e a interação entre identidades individuais e identidades coletivas; Kornberger e Clegg (2011) mostram tanto o strategizing como prática performativa, quanto a natureza performativa dos efeitos da estratégia; Vaara e Whittinghton (2012) enfatizam o estudo sobre as identidades e os papéis dos praticantes como um caminho para a pesquisa da prática em estratégia; Denis, Langley e Rouleau (2007) e Rouleau (2013) analisam como gestores e outros praticantes "performam" a estratégia, considerando tanto a interpretação do contexto quanto os elementos do strategizing em um nível micro; Mirabeau, Maguire e Hardy (2018) analisam as práticas relacionadas a comportamentos estratégicos induzidos por meio de estratégia pretendida e deliberada, não necessariamente realizada, e comportamentos estratégicos autônomos conduzidos por meio de estratégia emergente e efêmera, que podem levar à estratégia realizada; e, por fim, Burgelman et. al (2018) analisam a importância da identidade dos estrategistas e a identidade e subjetividade de atores externos para a construção da estratégia.

\section{Estudos culturais e bandas de música: articulando estilos e identidades}

Uma variedade de termos tem sido utilizada "para descrever as relações entre os trabalhos de arte e seu contexto social", dentre eles, tem-se o termo "estilos" (Becker, 1974, p. 767). Em uma análise sociológica do gosto e estilo na música, Peterson e Kern (1996, p. 904) propõem que o "onivorismo cultural" na sociedade contemporânea não designa um consumo/gosto por qualquer coisa indiscriminadamente, mas uma "disposição/abertura para apreciar qualquer coisa" e, consequentemente, para a exclusão e discriminação de outras coisas ou daqueles que delas gostam. Os autores analisam a relação música country, jazz, blues, rock e bluegrass. 
Em uma cartografia das sociabilidades do espaço urbano, Straw (2006) fala da persistência do uso do conceito de cena no estudo das artes, por sua natureza flexível e antiessencialista, mas alerta para evitar-se o isolamento do agenciamento político, das relações e regimes econômicos e das sensibilidades dos fenômenos culturais urbanos. O conceito de cena musical é analisado por Pereira e Pontes (2017), em articulação com consumo (produção e recepção), moda, estilos de vida, identidades e ethos alternativos em experiências e imaginários juvenis. Hesmondhalgh (2005) analisa o uso e as limitações dos termos "subculturas", "cenas" e "tribos" e sugere o termo "gênero musical" em estudos sobre música popular; também Born (2011) analisa o conceito de gênero musical.

Os estudos da arte, enquanto produto social produzido por uma organização social ou coletivo de ações, para Becker (1974), não podem prescindir de pesquisar as pessoas que constituem este coletivo e suas ações. Em uma perspectiva dos estudos culturais, teóricos da sociologia, da antropologia e da mídia, comunicação e cultura de massa, analisam a articulação entre estilos e identidades. Bourdieu (2013, p. 56), ao analisar a implicações entre senso estético e senso de distinção, propõe que a disposição estética é "a expressão distintiva de uma posição privilegiada no espaço social" e os gostos, enquanto "produto dos condicionamentos associados a uma classe particular de condições de existência", unem e separam os indivíduos. O autor lembra que a "intolerância estética exerce violências terríveis"; visto que as tomadas de posição estéticas, "objetiva ou subjetivamente [...] constituem outras tantas oportunidades de experimentar ou afirmar a posição ocupada no espaço social como lugar a assegurar ou distanciamento a manter" (Bourdieu, 2013, p. 57). Para o autor existe uma correspondência entre a produção de bens e a produção de gostos e estilos de vida.

É por meio da linguagem e dos sistemas simbólicos que as identidades adquirem sentido e são representadas (Woodward, 2000, p. 10) e, por ser relacional e histórica, a identidade é marcada pela diferença e "a construção de identidade é tanto simbólica quanto social”. Por meio da representação e da criação de significados são produzidas as identificações e, além disso, as identidades são constadas como nós com os outros (Woodward, 2000). Para Hall (2000, p. 106), a identificação é "um processo de articulação nunca completado". O autor faz referência ao termo freudiano "consumir o outro" e ressalta a natureza discursiva e simbólica desse processo. Por serem construídas/produzidas em locais específicos, no interior de práticas e estratégias específicas, as identidades precisam ser compreendidas dentro do discurso e das relações de poder.

O circuito da cultura ou das práticas culturais envolve inter-relações entre: representação, identidade, produção, consumo, regulação (Hall, 2016, p. 18). Dentre outros aspectos de sua análise, ele mostra que "sons, palavras, gestos, expressões, roupas são parte de nossa realidade natural e material, elas também "fazem" algo mais: "carregam sentido", "constroem significados e os transmitem" (Hall, 2016, p. 24).

Em uma análise da cultura contemporânea, Hall (2016, p. 140) propõe a ideia do "espetáculo do "outro'": uma "variedade de imagens expostas na cultura popular e na cultura de massas", as práticas representacionais de 
"estereotipagem", as diferentes estratégias que buscam intervir no campo da representação e direcionar as práticas de representação.

A música tem papel marcante na materialização de identidades, analisa Born (2011), devido a sua socialidade plural. A autora propõe a metáfora topológica de quatro planos de mediação social (ou socialidades) da música na materialização das identidades: prática musical, experiência musical, condições sociais e condições institucionais. Uma relação de autonomia e condicionamento entre esses quatro planos contribui para os estudos da mútua mediação (e das relações contingentes) entre identidades sociais e gêneros musicais. Em relação à capacidade da música "mediar e mobilizar formação de identidades", Born (2011, p. 379-383) cita: (a) a possibilidade da teoria do gênero musical e dos afetos iluminar um emaranhamento entre formações sociais e musicais", ou, o "poder da música para criar agregações afetuais"; (b) a capacidade da música para estimular/gerar "comunidades imaginadas", "coletividades virtuais", "identificações fantasiadas" e "identidades emergentes"; e, (c) a interação entre relações sociais (amplas) e os sistemas de gênero musical e a possibilidade de articulação entre comunidades musicalmente imaginadas e identidades sociais.

Em sua análise dos estilos de vida e da cultura de consumo de massa em uma sociedade pós-moderna, Featherstone (1995, p. 119-120) afirma que ambos conotam "individualidade [do gosto], auto-expressão e uma consciência de si estilizada" e "as mudanças nas técnicas de produção e a segmentação do mercado" possibilitam mais opções de escolha; os estilos de vida implicam "que estamos rumando para uma sociedade sem grupos de status fixos", é o "triunfo da representação".

Considerando que "a estetização da realidade coloca em primeiro plano a questão do estilo" (Featherstone, 1995, p. 122), o autor argumenta que é proveitoso perguntar: quais grupos ou frações de classes estão diretamente "envolvidos com a produção simbólica", de imagens e informações, e "que estilos de vida são celebrados" numa dinâmica relacional de determinações e oposições do gosto.

As pressuposições acerca de uma relação necessária entre identidades sociais (raça, sexo, idade), gosto e expressão musical são questionadas por Frith (1996) em sua análise das práticas cotidianas de pessoas produzindo e ouvindo música. Ele argumenta que, de um ponto de vista pós-moderno, "músicas feitas em algum lugar por alguma razão podem ser imediatamente apropriadas em outro lugar por uma outra razão distinta", pois "enquanto a música pode ser modelada pela primeira pessoa que a fez e a usou, enquanto experiência ela tem uma vida própria (Frith, 1996, p. 109). Com ênfase nas pessoas produzindo e ouvindo música, Frith (1996, p. 121) afirma que "a experiência da música pop é uma experiência de identidade" e essa experiência é obviamente, por vezes, coletiva.

Estudos que buscam relacionar identidade e música, com uma proposta homológica, tendem a desconsiderar o "caráter fragmentário" dos processos de identificação. Para Vila (2012, p. 267), a "compreensão da relação complexa que as pessoas estabelecem com a música" pode ser mais exitosa se o foco da análise for as práticas musicais, entendidas como práticas variadas e contraditórias. Além disso, as complexas combinações 
de práticas sobre som, letra e performance podem estar vinculadas ao processo fragmentado de construção de identidades. De acordo com Vila (2012, p. 268), a relação entre identidade e música é um encontro entre dois atos discursivos e performativos. Tais encontros se desenvolvem como uma trama de intercâmbios simbólicos, identidades imaginadas, reivindicação de identidades e mais ou menos estruturação (grau de improvisação).

\section{- Bandas de música: estratégias e práticas}

Além dos aspectos performáticos relacionados com o ritmo e a execução musical das bandas, essas se constituem como um grupo de profissionais que constituem unidades organizacionais (Murnighan \& Conlon, 1991; Shuker, 1999). Na dinâmica das bandas, sobressaem-se diversos aspectos estratégicos que podem influenciar a existência e os resultados da banda (Cohen, 1991; Murnighan \& Conlon, 1991; Davidson \& Good, 2002; Janotti, 2006).

As bandas musicais devem adotar um gênero musical já existente, visando a entrada no mercado musical e o reconhecimento artístico; ou podem inovar, produzindo um novo subgênero musical, como fizeram as bandas de punk (rock) e grunge (rock alternativo), respectivamente, em meados dos 1970 e nos anos 1980 (Kelly, 2007). Esses dois subgêneros são emblemáticos porque mostram que, além da dimensão propriamente musical (sonora), a estratégia em uma banda está relacionada com a sua capacidade de ser comercial (aspectos econômicos) e com suas práticas estéticas, estilo de vida e posicionamentos políticos. Também mostram a relação entre o reconhecimento artístico das bandas e a cultura, a política e as condições econômicas e tecnológicas da época (Benner \& Waldfogel, 2016). Um exemplo, no Brasil, foi a criação de bandas do subgênero tecnobrega que trouxeram também novas formas de produção e distribuição (Gomes, 2007; Lemos \& Castro, 2008).

A mudança social provocada pelas bandas ultrapassa as fronteiras de um país como a "atitude Ramones", que não foi um processo totalmente aleatório ou que ocorreu unicamente ao acaso. Existe indícios de que os músicos deliberadamente criaram esse estilo, definindo, pelo menos, boa parte das suas regras e práticas da banda em entrevistas, nos shows nas capas dos discos, conforme depoimento do guitarrista da banda Johnny Ramone (Melnick \& Meyer, 2003). O resultado desse conjunto de ações, comportamentos e regras fez com que a banda se diferenciasse das outras no período, conquistando fãs, críticos e a mídia.

Em estudo sobre o papel dos estrategistas no desenvolvimento da "estratégia artística" de uma orquestra sinfônica, Maitlis e Lawrence (2003) mostram que a estratégia artística precisa ter, além da identidade sonora e estética, também uma perspicácia comercial e a capacidade de articular essas questões em torno de uma estratégia central. O estudo mostrou que as falhas no processo de "strategizing" ocorrem na interface dos recursos discursivos (discurso organizacional) e dos comportamentos políticos (posicionamento político) que envolvem também interpretação, legitimação e disputas por poder. 
Em um estudo com quartetos de músicos de cordas, na Inglaterra, Murnighan e Conlon (1991) revelaram que três aspectos organizacionais influenciaram positivamente os resultados dos quartetos pesquisadas, dentre eles: (1) a liderança democrática exercida geralmente pelos músicos que possuíam mais conhecimento técnico; (2) a administração de conflitos realizada por meio de uma variedade de estratégias; (3) foco e compromisso do grupo com os resultados coletivos acima das dificuldades advindas da diversidade e as diferenças entre os membros dos quartetos. Mesmo que os membros do grupo apresentem gostos musicais, estilos de composição e personalidades diferentes, esses fatores eram menos importantes do que o objetivo de realizar apresentações maravilhosas, quase como uma obsessão pelos quartetos de músicos.

Em um estudo com duas bandas inglesas, em Liverpool, Cohen (1991) mostrou que as estratégias de atuação das bandas eram marcadas por discussões constantes que envolviam tensão e que, eventualmente, abalavam o relacionamento entre os membros. No universo organizacional das bandas estudadas, era evidente o conflito de opiniões entre os integrantes da banda, as quais se dividiam entre: foco na criatividade ou foco no mercado, nas estratégias de parceria com gravadoras independentes ou parceria com grandes gravadoras, no investimento na qualidade musical ou no conteúdo. Ainda assim, o processo criativo dessas bandas era tipicamente participativo (Cohen, 1991).

Em relação à estratégia ou à existência de uma banda de música, destacam-se quatro características. A primeira está relacionada às práticas estratégicas das bandas e às atividades desempenhadas pelos músicos, vistas como um trabalho técnico e de habilidades altamente especializados, de modo que esses possuem, em geral, papel estratégico dentro da organização, com representativo poder e influência. Uma segunda característica da estratégia em uma banda musical diz respeito às diversas possibilidades de atuação no mercado, que caracteriza o tipo de banda/grupo que será criada: o trabalho cover, tributo, autoral e orquestra (Shuker, 1999; Salazar, 2010). A atuação no mercado implica questões econômicas/mercado/oportunidades e culturais/valores/estilos e envolvem diferentes tipos de negociação e práticas dos músicos líderes (Shuker, 1999; Janotti, 2006).

A terceira característica da estratégia é a forma de atuação de uma banda musical, que diz respeito à escolha do gênero musical. Gênero pode ser definido como uma categoria ou um tipo (Shuker, 1999) que, independentemente de conhecer o intérprete, o consumidor de música reconhece as melodias, as temáticas e as expressões (Janotti, 2006). Os fãs e consumidores da música, as bandas, indústrias e lojas etc. frequentemente situam o seu trabalho segundo o gênero e os estilos musicais (Shuker, 1999). A definição do gênero musical envolve três fatores, segundo Janotti (2006): (a) regras econômicas/convenções de mercado (como a música é embalada); (b) regras semióticas (estratégias de produção nos produtos musicais); e (c) regras técnicas e formais (produção e recepção musical). As bandas musicais são influenciadas, desse modo, pelas categorias de marketing da indústria fonográfica e por padrões/convenções socialmente aceitos, de acordo com o gênero musical (Frith, 1987). 
A quarta característica da estratégia é a forma de articulação entre as apresentações da banda e os bastidores dessas apresentações. Os artistas de bandas musicais ao mesmo tempo criam e se ajustam ao ritual de apresentações, ao adotar imagens, estilos e performances associados a gêneros específicos (Shuker, 1999). As apresentações das bandas musicais são fenômenos culturais, constituídos por uma mistura de música e negócio, de ritual e prazer (Shuker, 1999), além de envolver também afirmação e celebração dos valores musicais, avaliação dos críticos, mobilização dos fãs e apoio de uma comunidade. O êxito do espetáculo exige interações diversas entre banda, empresário, patrocinadores, técnicos e assistentes, cronograma rígido, dentre outros.

\section{Drocedimentos metodológicos}

Esta pesquisa tem como base abordagens pós-estruturalistas que emergiram como crítica ao positivismo e ao interpretativismo em sua vertente cognitivista (Ezzamel \& Willmott, 2010). O método de procedimento adotado foi um estudo de múltiplos casos que contribui, em especial, para a compreensão dos fenômenos sociais, organizacionais e individuais complexos (Yin, 2005). Ademais, a abordagem do material pesquisado é qualitativa.

O público pesquisado é composto por 15 músicos e 2 empresários de 11 bandas; no momento da entrevista, somente 2 bandas tinham a figura do empresário. A pesquisa mostrou que os 15 músicos entrevistados desempenham mais de um papel na banda e são ou estão dentre aqueles que exercem o papel de estrategistas. As bandas têm diferentes formas de inserção no mercado da música, diferentes gêneros musicais e média de tempo de mercado de 14 anos, conforme apresentado na Tabela 1. A pesquisa com bandas diferentes buscou mostrar a variedade de práticas de strategizing e de articulação entre identidades e estilos (estudos culturais). As bandas pesquisadas compõem a cena musical da cidade de Uberlândia e da região do Triângulo Mineiro, no estado de Minas Gerais. Essa cidade tem uma rica cena musical, com a presença de várias bandas e músicos que possuem escritórios e têm presença na cena musical da região e nacional.

A coleta de dados foi realizada por meio da triangulação (Denzin \& Lincoln, 2006): (a) pesquisa documental (Flick, 2009) em websites das bandas e de reportagens sobre as bandas em revistas e jornais; (b) entrevistas (Gaskell, 2010) individuais semiestruturadas realizadas face a face foram gravadas e transcritas; e (c) análise de fotos/imagens (Penn, 2010), presentes no website das bandas e que as mostravam durante uma performance ou preparadas para tal.

A análise das fotos foi realizada a partir da orientação de Penn (2010) para estudo de imagens paradas. A autora mostra que a análise semiótica de imagens paradas pode ser feita a partir de elementos denotativos (catalogação do sentido literal do material pesquisado), do sintagma (relações entre os elementos), de elementos conotativos/mitos (associações trazidas ou que se busca trazer à mente pelo material) e do conhecimento cultural (conhecimento exigido para a leitura do material). 
Tabela 1 - Bandas musicais pesquisadas

\begin{tabular}{|c|c|c|c|}
\hline $\begin{array}{l}\text { Banda de música, início de } \\
\text { atuação e website }\end{array}$ & $\begin{array}{l}\text { Estratégia de } \\
\text { inserção no } \\
\text { mercado musical }\end{array}$ & Gênero musical & Entrevistados \\
\hline $\begin{array}{l}\text { Banda Clic } \\
1980 \\
\text { www.bandaclic.com.br }\end{array}$ & Cover & Rock & $\begin{array}{l}\text { 1. Guitarrista, cantor, compositor e produtor musical } \\
\text { 2. Cantora e percussionista }\end{array}$ \\
\hline $\begin{array}{l}\text { Grupo Emcantar } \\
1996 \\
\text { www.emcantar.org.br }\end{array}$ & Autoral e cover & MPB & $\begin{array}{l}\text { 3. Atriz, cantora, produtora musical e comunicação } \\
\text { institucional } \\
\text { 4. Diretor geral, cantor e produtor musical }\end{array}$ \\
\hline $\begin{array}{l}\text { Lísias e banda } \\
2005 \\
\text { www.lisiasmesadebuteco.com.br }\end{array}$ & Cover & Samba e MPB & $\begin{array}{l}\text { 5. Músico, cantor e diretor geral } \\
\text { 6. Músico, cantor e produtor musical }\end{array}$ \\
\hline $\begin{array}{l}\text { Luiz Salgado e Quarteto Uai Fái Minas } \\
\text { Groove } \\
1997 \\
\text { www.luizsalgado.tnb.art.br }\end{array}$ & Autoral & $\begin{array}{l}\text { MPB e Caipira } \\
\quad \text { Raiz }\end{array}$ & $\begin{array}{l}\text { 7. Cantor, compositor, violão, produtor musical } \\
\text { 8. Empresária e produtora }\end{array}$ \\
\hline $\begin{array}{l}\text { Marco \& Mário } \\
2000 \\
\text { www.marcoemario.com.br }\end{array}$ & Autoral & Sertanejo & 9. Cantor e compositor \\
\hline $\begin{array}{l}\text { Porcas Borboletas } \\
1999 \\
\text { www.porcasborboletas.com.br }\end{array}$ & Autoral & Rock & 10. Sintetizador, designer e produtor \\
\hline $\begin{array}{l}\text { Tarcísio Manuvéi \& Viola de Nóis } \\
2000 \\
\text { www.violadenois.com.br }\end{array}$ & Autoral e tributo & Caipira Raiz & 11. Cantor, violeiro base, produtor e violonista \\
\hline $\begin{array}{l}\text { Venosa } \\
2007 \\
\text { www.venosa.tnb.art.br }\end{array}$ & Cover & Rock & $\begin{array}{l}\text { 12. Cantor e produtor musical } \\
\text { 13. Tecladista, guitarrista e publicitário }\end{array}$ \\
\hline $\begin{array}{l}\text { Viena Musical } \\
2013 \\
\text { www.vienamusical.com.br/ }\end{array}$ & Cover & $\begin{array}{l}\text { Música Clássica } \\
\text { e MPB }\end{array}$ & $\begin{array}{l}\text { 14. Cantor, violonista, sonorização e gravação, e } \\
\text { contato }\end{array}$ \\
\hline $\begin{array}{l}\text { WER } \\
2005 \\
\text { www.grupower.com.br/ }\end{array}$ & Tributo & Rock & $\begin{array}{l}\text { 15. Cantor, Produtor, Diretor Musical e administrador } \\
\text { 16. Empresário responsável pela gestão comercial, de } \\
\text { marketing e produção executiva do projeto }\end{array}$ \\
\hline $\begin{array}{l}\text { Yaya e banda } \\
1992 \\
\text { http://yayaecia.blogspot.com.br/ }\end{array}$ & Cover & $\begin{array}{l}\text { Axé, Pagode e } \\
\text { MPB }\end{array}$ & 17. Instrumentista (violão) e proprietário da banda \\
\hline
\end{tabular}

Fonte: elaborada pelos autores

Considerando que o strategizing envolve diferentes níveis de práticas e que a articulação entre identidades e estilos musicais (Becker, 1974; Vila, 2012) exige pesquisar o que as pessoas estão fazendo no dia a dia, foram identificadas a priori quatro categorias de análise, a partir da literatura especializada sobre bandas: (a) práticas sonora e musical da banda; (b) práticas estéticas da banda; (c) práticas de formação e composição da banda; e (d) 
práticas de crescimento e popularização da banda. O guia de entrevistas foi elaborado com questões sobre as práticas dessas quatro categorias. A análise de cada categoria de pesquisa foi realizada considerando quatro dimensões que emergiram do material pesquisado: (a) social/interativa; (b) comunicativa/ relacional; (c) aprendizagem/mudança; (d) uso de instrumentos de gestão.

\section{Apresentação e análise de resultados}

Inicialmente, as informações de 11 bandas e suas práticas, coletadas no website de cada banda, mostram a porosidade entre as práticas em diferentes níveis: a cultura (Featherstone, 1995, Vila, 2012), a indústria fonográfica e a indústria musical - sendo o strategizing como macro prática. A partir dessas informações e daquelas coletadas com as entrevistas realizadas com os músicos e empresários, foram analisadas as práticas em nível meso e intra organizacionais (Johnson, Melin, \& Whittington, 2003) das bandas musicais pesquisadas e os seus estrategistas (Shuker, 1999; Janotti, 2006), conforme apresenta a Figura 1.

Estratégia artística de uma banda: implica produzir arte que seja igualmente relevante para sua comunidade (pressões artísticas) e competitiva no mercado de entretenimento/cultural (pressões comerciais) (Maitlis \& Lawrence, 2003)

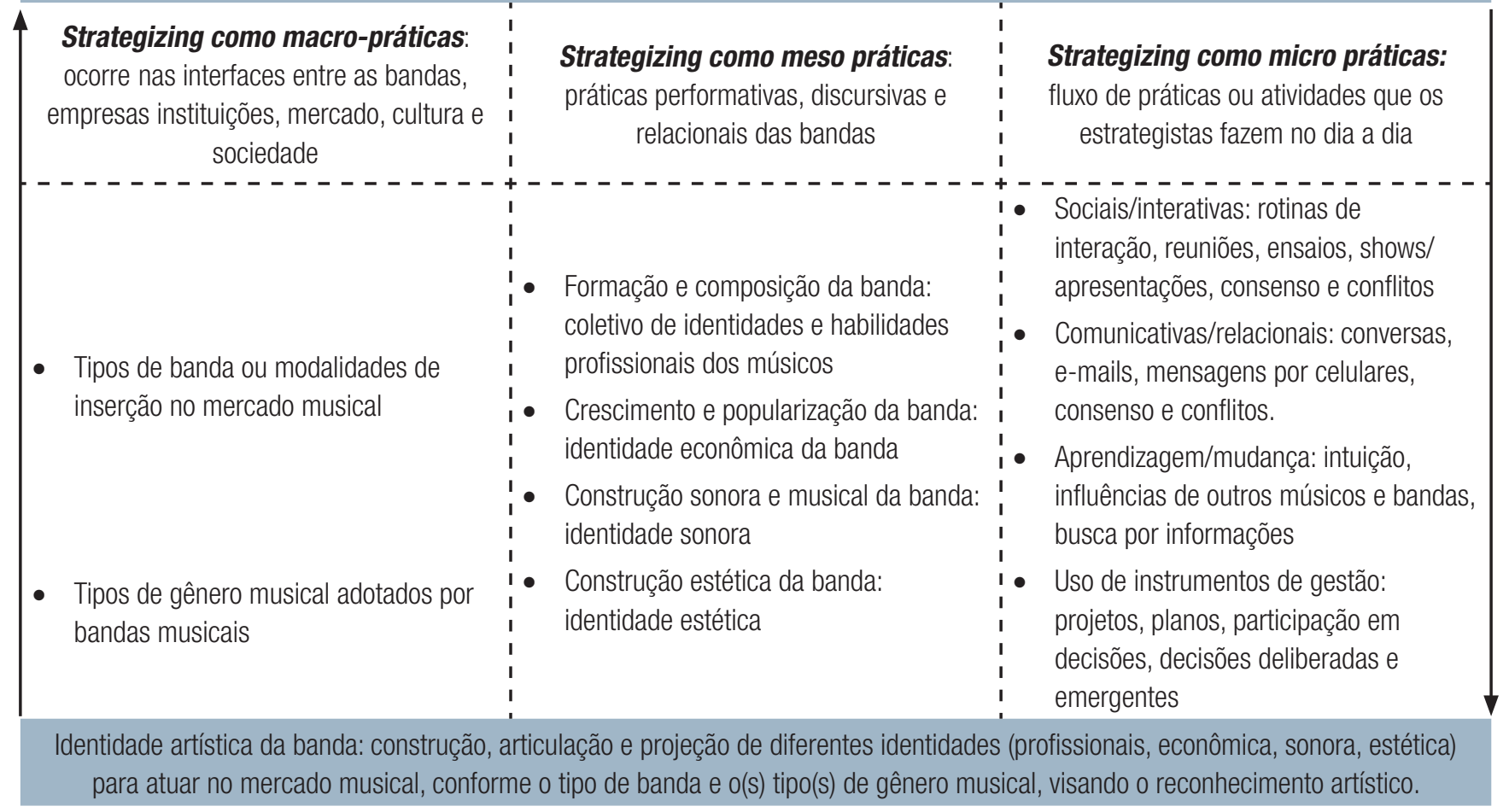

Figura 1. As estratégias de bandas musicais como prática social

Fonte: elaborada pelos autores.

Em relação à identidade sonora e musical das bandas, esta pesquisa mostrou que as bandas praticam três tipos diferentes de strategizing: práticas orientadas para o mercado; práticas sonoras e musicais intuitivas visando o aprimoramento musical da banda; (c) práticas influenciadas por 
ligações afetivo-emocionais (Samra-Fredericks, 2003) com aspectos sociais e religiosos que constituem parte da cultura e das origens dos músicos da banda (passado), com problemas e questões da época atual (presente) ou ainda com a imagem de um mundo ideal (futuro), conforme afirma Frith (1996). A música, por meio de letras e sonoridade, oferece uma experiência de identidade coletiva, além de poder ser apropriada para uso pessoal (Frith,1987), gerando identificação e vinculando-se a determinados momentos da vida de uma pessoa. Esses três tipos de strategizing parecem "estar em movimento" simultaneamente na produção de músicas por uma banda, para além dos aspectos econômicos e ideológicos (Shuker, 1999). A banda e as gravadoras dependem de resultados econômicos para a sua existência, mas os fãs esperam que elementos ideológicos e afetivos que sempre definiram a banda (mensagens de protestos, críticas ao governo, defesa da liberdade, relatos da própria história de vida ou a oferta de imagens de um mundo ideal) estejam presentes em um álbum e os críticos musicais esperam que a cada novo álbum a banda traga inovação e/ou aprimoramento musical.

O estilo musical da banda foi definido em consenso com o cliente e ele participa de todo o processo. É ele que traz o fio condutor, então as sugestões acontecem pontualmente. Se eu percebo que o cara não gosta de certa coisa, não adianta eu ficar persistindo naquilo (Entrevistado 14).

[...] a gente conversa também sobre a outra parte, que é o público, porque não adianta nada eu gostar de heavy metal e todo mundo da banda gostar de heavy metal e a gente querer tocar heavy metal para um público que não quer ouvir isso. Se nosso público é outro, a gente tem plena consciência de que num dia que a gente for tocar em um casamento, a gente vai tocar Daft Punk, Maroon 5 (Entrevistado 12).

[...] tudo o que a gente chegou até hoje, que a gente conseguiu foi sem querer... porque quando você pensa muito, faz reunião, aí dá tudo errado, aí falha. O negócio vai acontecendo, a gente sabe como que é, depende muito do presencial, quando a gente está ali mesmo com a galera junto. Aí [em algum momento] a gente faz um "intensivão", a gente se reúne não sei aonde, aí sai muita coisa, tipo a gente faz um disco por semestre (Entrevistado 10).

Surgiu naturalmente. Eu sempre gostei de ouvir coisas estranhas, algo que não estava muito na boca do povo [...] eu sou um cara que eu consigo ver as notas músicas, os acordes, todos, na minha mente, sem tocar, sem estar com o instrumento na mão. Então, eu componho muito viajando, no carro; eu já faço a harmonia, mesmo viajando; as concordâncias de acordes, aonde a letra vai encaixar, aquela palavra, procuro a palavra mais picante de uma frase; às vezes, não parece importante, mas ela me causou impacto e deu ritmo, na minha cabeça (Entrevistado 1).

[...] a minha principal influência são as Folias de Reis, que foi onde eu cresci aprendendo essa função, ouvindo, depois que eu vim para Uberlândia, me apaixonei por Congo, Moçambique, até gravei um CD [em parceria] só de congado e Moçambique (Entrevistado 7).

[...] ideologicamente, a nossa base foi pesquisar a nossa cultura: aquilo que estava próximo de nós. Nós fizemos esses documentários, que estão no site da Emcantar. [...] também sempre teve o pilar sócio ambiental do nosso trabalho. Essa defesa da vida em última instância, a vida que, do ponto de vista das relações, nós estabelecemos em primeiro lugar eu comigo mesmo, depois eu com o outro ou eu em sociedade, e eu com a natureza física [...]. Então, nesse conjunto das três ecologias, a gente fundamentou a nossa defesa e a nossa bandeira da educação socioambiental (Entrevistado 4). 
As bandas pesquisadas são conduzidas pelos músicos líderes (Murnighan \& Conlon, 1991) e as decisões estratégicas são realizados de forma compartilhada na maioria das bandas estudadas. A baixa presença do processo consensual nas decisões e políticas da identidade sonora e musical foi identificada em uma minoria das bandas. Nesses casos, a decisão é centralizada em um líder ou pequeno grupo de líderes.

[...] e de repente alguém tem uma ideia... [essa pessoa] vai e faz a música, e outro vem e faz uma sugestão, faz aquela lapidação até [o momento] de ir para o estúdio e virar todo esse trabalho musical. É difícil explicar como funciona, porque é muito intuitivo [...] é de colocar os ouvidos atentos para captar e isso por meio de todos os sentidos que a gente tem, transformar isso em música (Entrevistada 3).

[...] geralmente, eu sou o ponto de partida. Mas tem muita participação do [...] meu irmão [membro da banda]. Ele é muito intenso também na participação dele, essas coisas assim, na composição das músicas, entendeu. Mas geralmente eu sou, eu sou o embrião (Entrevistado 1).

Todas as bandas pesquisadas têm projetos e planos para novos produtos como shows, CD's e DVD's, novas formas de receita como projetos de leis de incentivo. Além dos álbuns, uma prática importante na construção da identidade sonora e musical das bandas são os shows. Esta pesquisa identificou dois tipos de estratégias referentes aos shows: (a) estratégia emergente em shows ocorre na maioria das bandas; (b) estratégia de deliberada para shows ocorre em menos da metade das bandas pesquisadas. $\mathrm{Na}$ estratégia emergente, as bandas possuem um roteiro para os shows, entretanto, esse roteiro é uma estratégia efêmera (Mirabeau, Maguire, \& Hardy, 2018) que sofre alterações substanciais de acordo com o público, com a intuição/ criatividade do artista ou outro elemento. Na estratégia deliberada para shows, as bandas seguem grande parte do roteiro planejado.

A gente monta todo o boneco [roteiro dos shows] ali para uma turnê. Só que o show da turnê precisa ter flexibilidade, porque às vezes você vai tocar em diferentes regiões e tem região que é mais dançante, tem região que é mais romântica (Entrevistado 9).

[...] eu considero como um talento que pode dar muito errado, mas geralmente dá certo, que é conseguir ler a plateia. Eu tenho esse negócio [estratégia], eu levo um repertório, [...] as duas primeiras músicas eu vou no roteiro para sacar a plateia, mas no meio, eu já mudo tudo ou não... tem um... o esqueleto está ali, mas eu gosto disso, desse improviso. (Entrevistado 7).

[...] por exemplo, no show a gente sente muito a temperatura do público. Então se o público está mais só querendo ouvir, a gente toca determinadas músicas, se o público está a fim de dançar, a gente toca outras coisas. A gente muda na hora o repertório, a gente sente a temperatura do público (Entrevistado 1).

[...] é bem planejado. É bem planejado, visto também que, às vezes, você tem que fazer uma apresentação do grupo em até uma hora, sendo que também o seu cliente está se mexendo, girando vários pratos ao mesmo tempo. Tem a vida dele e ele está cuidando de um evento que vai ser muito grande na vida dele, ele quer tudo 100\%. O cliente quer ter a certeza que o evento dele vai ser 'o evento' (Entrevistado 14).

A identidade estética das bandas musicais pesquisadas (Tabela 2 e Imagens 1, 2 e 3) pode estar associada ao gênero musical, contudo existem diversas variações dentro de um mesmo gênero. A estética musical é fonte de identificação cultural e de consumo de estilos (Born, 2011; Featherstone, 1995, Vila, 2012). 
Tabela 2 - Análise semiótica das fotos das bandas quanto à identidade estética

\begin{tabular}{|c|c|c|c|}
\hline $\begin{array}{l}\text { Banda } \\
\text { de } \\
\text { música }\end{array}$ & Denotação & Conotação & Conhecimento cultural \\
\hline 졸 음 & $\begin{array}{l}\text { Músicos vestindo camisetas, calça jeans, } \\
\text { bonés, predominância de roupas pretas, poucos } \\
\text { acessórios. }\end{array}$ & $\begin{array}{l}\text { Estilo casual, ou seja, ao acaso, das rotinas } \\
\text { do dia a dia sem planejamento, despojado. }\end{array}$ & $\begin{array}{l}\text { Referências às origens do gênero musical } \\
\text { rock, simplicidade e despojamento e } \\
\text { autonomia. }\end{array}$ \\
\hline 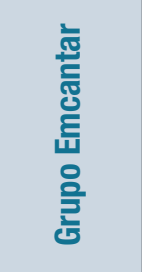 & $\begin{array}{l}\text { Todos os músicos utilizam pinturas no rosto, } \\
\text { alguns com um tipo específico de chapéu, ou } \\
\text { outros acessórios na cabeça. Todos vestem } \\
\text { roupas coloridas, aparentemente feitas de malha, } \\
\text { com pinturas, bordados e estampas etc. }\end{array}$ & $\begin{array}{l}\text { Estilo capaz de transmitir informação } \\
\text { e emoção, devido às diferentes cores, } \\
\text { desenhos e elementos culturais remetendo } \\
\text { a elementos circenses, teatro e danças } \\
\text { regionais do Triângulo Mineiro. }\end{array}$ & $\begin{array}{l}\text { Referências ao figurino e maquiagem } \\
\text { do circo moderno, misturados com } \\
\text { elementos de festas regionais como } \\
\text { Congado e Folia de reis. Estrutura } \\
\text { plástica e elementos combinados: } \\
\text { textura, forma e cor; todos conectados ao } \\
\text { estilo da roupa e pinturas corporais. }\end{array}$ \\
\hline 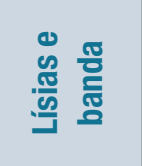 & $\begin{array}{l}\text { Músicos com roupas brancas, ambos com chapéu } \\
\text { palha de samba carioca e elementos ligados } \\
\text { ao samba, como cavaquinho e colares e outros } \\
\text { acessórios. }\end{array}$ & $\begin{array}{l}\text { wEstilo com elementos que transmitem } \\
\text { elegância, sedução e, ao mesmo tempo, } \\
\text { descontração. }\end{array}$ & $\begin{array}{l}\text { Referências ao estilo samba urbano } \\
\text { carioca dos primeiros sambistas: } \\
\text { malandro carioca, marginalizado, terno } \\
\text { branco e chapéu de palha. }\end{array}$ \\
\hline 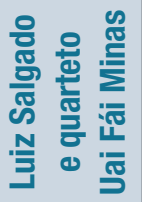 & $\begin{array}{l}\text { Músicos vestem roupas de malha e camisas } \\
\text { xadrez com acessórios coloridos, como colete e } \\
\text { fitas coloridas. } 0 \text { palco apresenta elementos de } \\
\text { decoração diversos, como artesanatos, tecidos de } \\
\text { pano pintados ou bordados, barro e madeira }\end{array}$ & $\begin{array}{l}\text { Estilo que traz elementos da estética como } \\
\text { roupas, acessórios e cenários ligados aos } \\
\text { elementos da simplicidade da vida do } \\
\text { campo e da religião. }\end{array}$ & $\begin{array}{l}\text { Referências aos traços culturais } \\
\text { e religiosos do Congado, cultura } \\
\text { afrodescendente e da Folia de Reis, festa } \\
\text { católica que celebra os três Reis Magos. }\end{array}$ \\
\hline $\begin{array}{l}\infty \\
\text { 율 :을 } \\
\text { 产 } \\
\sum\end{array}$ & $\begin{array}{l}\text { Músicos utilizam roupas sociais e esporte fino, } \\
\text { com acessórios de metais e cabelos curtos, } \\
\text { combinados com a logomarca da dupla sertaneja. }\end{array}$ & $\begin{array}{l}\text { Estilo elegante que remete ao conceito } \\
\text { do homem urbano e moderno com leve } \\
\text { influência do country americano. }\end{array}$ & $\begin{array}{l}\text { Referências ao sertanejo universitário, } \\
\text { gênero que investe fortemente na } \\
\text { estética corporal, corte de cabelo, roupa } \\
\text { mais justa. }\end{array}$ \\
\hline 焉 & $\begin{array}{l}\text { Músicos utilizam roupas que variam entre } \\
\text { esportivas, camisetas básicas ou camisas } \\
\text { estampadas. Cada músico estabelece uma } \\
\text { postura corporal diferente. Alguns usam cabelos } \\
\text { longos e outros, com barba. }\end{array}$ & $\begin{array}{l}\text { Estilo remete a uma certa desordem } \\
\text { e desleixo, movimento corporais } \\
\text { aleatórios que trazem uma mensagem de } \\
\text { independência e liberdade. }\end{array}$ & $\begin{array}{l}\text { Referências movimento punk e ao } \\
\text { movimento de contracultura brasileira da } \\
\text { década de } 1970 .\end{array}$ \\
\hline 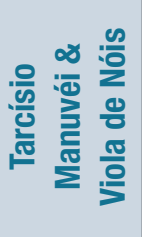 & $\begin{array}{l}\text { Músicos vestidos de calça jeans, camisa com } \\
\text { predominância do xadrez e a maioria com uso de } \\
\text { chapéu. Dois dos músicos seguram instrumentos, } \\
\text { sendo um deles uma viola caipira e o outro, um } \\
\text { violão. No cenário, existem artefatos que remetem } \\
\text { a artigos religiosos e uma árvore. }\end{array}$ & $\begin{array}{l}\text { Estilo com forte estilo caipira, roupas } \\
\text { simples e marcantes, com o uso da } \\
\text { tradicional calça jeans e camisa xadrez e } \\
\text { chapéu. Remete ao estilo da fazenda. }\end{array}$ & $\begin{array}{l}\text { Referências à cultura caipira que está } \\
\text { ligada aos moradores da roça. }\end{array}$ \\
\hline 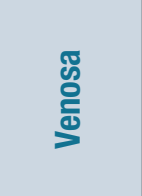 & $\begin{array}{l}\text { Músicos estão, aparentemente, em um bar, } \\
\text { tomando cerveja; um deles, fumando. Eles se } \\
\text { vestem, na maioria, com camisetas lisas ou } \\
\text { estampadas. Alguns deles utilizam acessórios, } \\
\text { como brincos, pulseiras, óculos etc. }\end{array}$ & $\begin{array}{l}\text { Estilo com estética, predominantemente, } \\
\text { de uma banda de rock com elementos do } \\
\text { pop moderno. } 0 \text { vocalista representa o } \\
\text { tradicional front man (homem de frente) da } \\
\text { banda: cabelos longos, brinco, pulseira. }\end{array}$ & $\begin{array}{l}\text { Referências aos padrões de conhecidos } \\
\text { vocalistas do rock, com destaque para as } \\
\text { atitudes marcantes no palco. }\end{array}$ \\
\hline
\end{tabular}




\begin{tabular}{|c|c|c|c|}
\hline $\begin{array}{l}\text { Banda } \\
\text { de } \\
\text { música }\end{array}$ & Denotação & Conotação & Conhecimento cultural \\
\hline 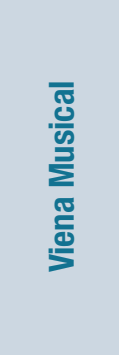 & $\begin{array}{l}\text { Os músicos da banda utilizam traje social (terno } \\
\text { e gravata). Alguns músicos tocam instrumentos, } \\
\text { geralmente, utilizados em músicas clássicas } \\
\text { (piano, violino etc.). Dois músicos se posicionam } \\
\text { à frente e bem próximos um do outro, aparentam } \\
\text { ser os vocalistas. A vocalista feminina se destaca } \\
\text { com um vestido com cores diferentes dos demais } \\
\text { músicos. } 0 \text { restante dos músicos utiliza as } \\
\text { mesmas cores (preto, branco e vermelho). }\end{array}$ & $\begin{array}{l}\text { Estilo formal e elegante, percebido tanto } \\
\text { nas roupas, como cortes de cabelo, } \\
\text { penteados, postura corporal e os } \\
\text { instrumentos nas mãos dos músicos. Os } \\
\text { músicos de frente, os vocalistas, remetem } \\
\text { a uma casa, por estarem muito próximos } \\
\text { e à frente dos demais e com as cabeças } \\
\text { inclinadas, um para o outro. }\end{array}$ & $\begin{array}{l}\text { Referências ao estilo da música clássica } \\
\text { erudita que, na sua origem, está } \\
\text { vinculada a músicas que não pertencem } \\
\text { às tradições folclóricas e populares. }\end{array}$ \\
\hline$\stackrel{\text { 虫 }}{ }$ & $\begin{array}{l}\text { Músicos vestem roupas como ternos com cortes } \\
\text { modernos, coletes, camisa. Também utilizam } \\
\text { acessórios como óculos, chapéu, pulseira e } \\
\text { anéis. Existe uma predominância da cor preta. }\end{array}$ & $\begin{array}{l}\text { Estilo que conecta novo e antigo, social e } \\
\text { jovial, clássico e pop. Ao mesmo tempo, } \\
\text { utilizam roupas formais com acessórios } \\
\text { modernos que remetem à cultura pop. }\end{array}$ & $\begin{array}{l}\text { Referências ao estilo consagrado da } \\
\text { banda Bee Gees que foi influente na } \\
\text { década de } 1970 \text { e } 1980 .\end{array}$ \\
\hline 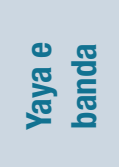 & $\begin{array}{l}\text { Dentre os músicos, a maioria utiliza camiseta e } \\
\text { calça jeans. Alguns deles estão com bonés. Dentre } \\
\text { os instrumentos, destacam-se o cavaquinho e as } \\
\text { percussões, violão e contrabaixo. }\end{array}$ & $\begin{array}{l}\text { Estilo descontraído, sem muito } \\
\text { planejamento, com roupas que poderiam } \\
\text { ser utilizadas no dia a dia. }\end{array}$ & $\begin{array}{l}\text { Referências ao estilo do pagode } \\
\text { brasileiro: informal, como uma situação } \\
\text { de um encontro entre amigos. }\end{array}$ \\
\hline
\end{tabular}

Fonte: elaborado pelos autores a partir de Penn (2010)

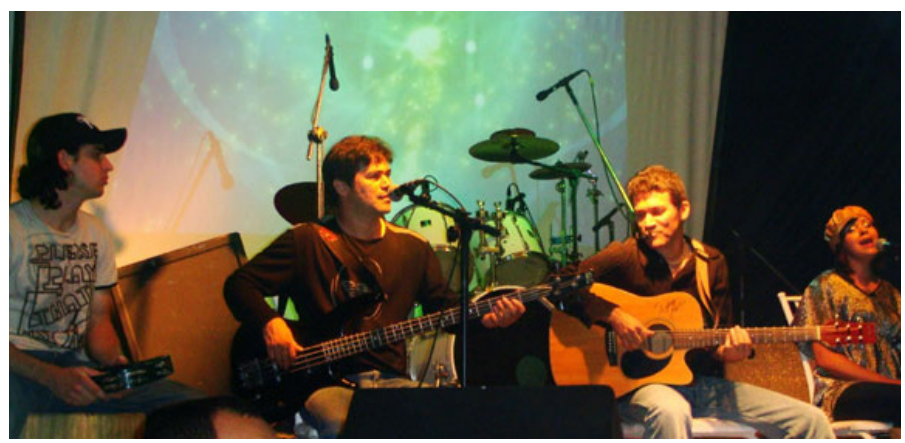

Imagem 1. Foto Banda Clic

Fonte: www.bandaclic.com.br (2015)

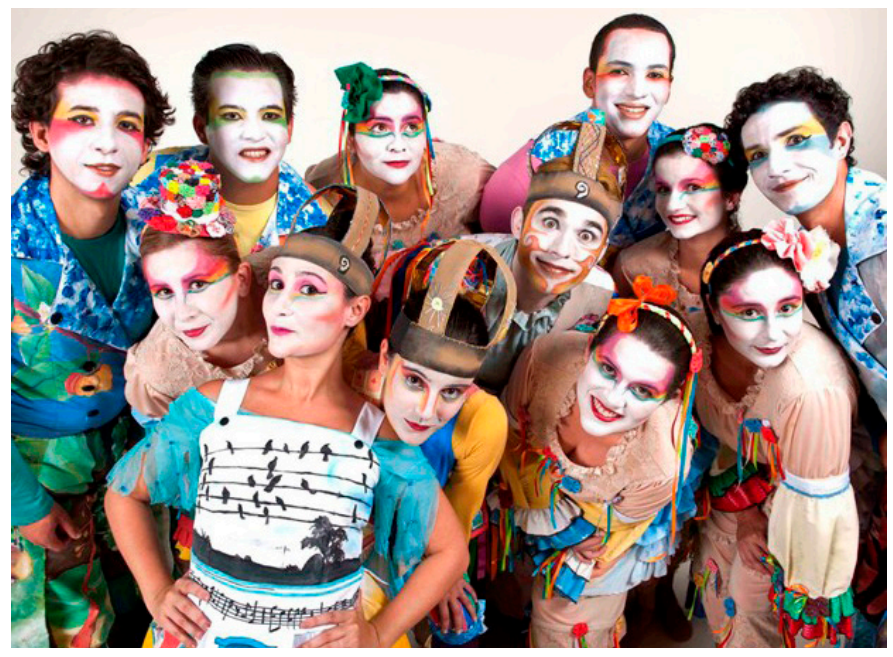

Imagem 2. Foto Grupo Emcantar

Fonte: www.emcantar.org.br (2015) 


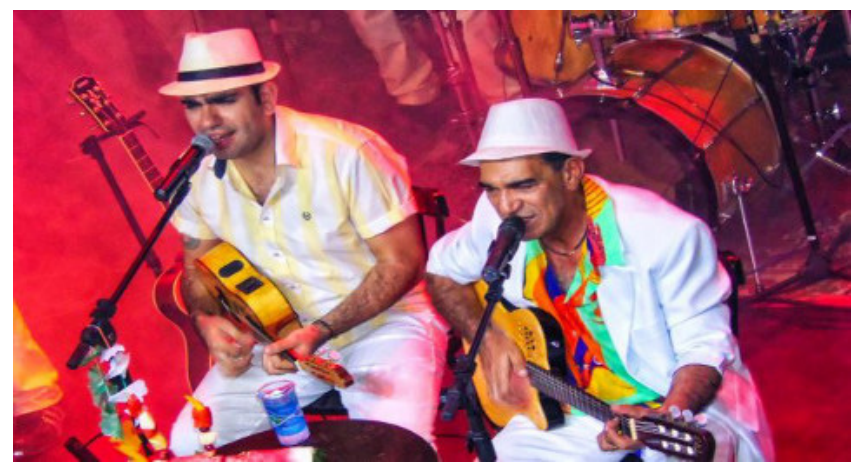

Imagem 3. Foto Lísias e Banda

Fonte: www.lisiasmesadebuteco.com.br (2015)

A identidade estética da banda ilustra o emaranhado entre a música e o social analisado por Born (2011, p. 379), pois exige uma análise interescalar de "como as socialidades engendradas por performances musicais são implicadas por relações sociais mais amplas"; como mundos ou comunidades musicalmente imaginadas podem gerar tão somenteidentificações fantasiadas ou podem prefigurar identidades emergentes. Vila (2012, p. 252) argumenta que a música (letra, melodia e interpretação) "oferece maneiras de ser e de comportar-se e também modelos de satisfação psíquica e emocional", ou seja, as bandas oferecem modelos para uma identificação étnica, de classe, de gênero etc. Para Vila (2012) é crucial entender a materialidade musical, ou seja, como a música passa do reino da oferta discursiva para a produção real ou concreta de identificação individual e coletiva.

Em uma análise da relação entre a arte, a estetização da vida cotidiana e o desenvolvimento de uma cultura de consumo, Featherstone (1995, p. 102) considera que, na sociedade pós-moderna, o fluxo incessante de "imagens diversas torna difícil encadeá-las em uma mensagem dotada de sentido". Esse fluxo incessante de imagens e a busca por se destacar parecem constituir um dos desafios das bandas na construção de sua identidade estética, e poderia explicar o uso de estratégias deliberadas (Mirabeau, Maguire, \& Hardy, 2018) pela maioria das bandas pesquisadas. A estratégia intuitiva e emergente é utilizada por menos da metade das bandas pesquisadas. $\mathrm{Na}$ estratégia deliberada da identidade estética, as bandas têm rotinas e práticas a respeito das formas, cores, aparatos, vestimentas, entre outros aspectos, que definem um estilo da produção artística; na estratégia intuitiva e emergente, as bandas definem suas práticas estéticas sem utilizarem qualquer processo de planejamento formalmente estruturado.

[...] traz a identidade do Triângulo Mineiro, desde a questão do tecido que a gente usa, ao que a gente leva para o palco, sejam costumes da região, sejam canções daqui que vão ficando esquecidas. E a gente faz uma pesquisa e leva isso como uma folia, que a gente grava no CD e leva para o palco. Então, é uma coisa de... você ser universal sendo regional (Entrevistada 3).

Nós visitamos várias cidades, [...] pesquisamos sobre Folia de Reis, que é outra manifestação distinta da Congada, outra sobre o Pena Branca, que é outro artista da região [...] o Seu Charqueada, que era um ancião [...]. Então ideologicamente, a nossa base foi pesquisar a nossa cultura, aquilo que estava próximo de nós (Entrevistado 4). 

importante a bota. Porque a bota tem ter solado de madeira por causa do barulho... o chapéu, enfim, a veste é normal. Então a viola... tem toda essa questão de lá atrás [tradição], então a gente tem que passar... as pessoas têm que saber disso, e, eu acho que é uma forma que você tem... Um espaço que você pode ter, é um memorial para que você possa falar disso (Entrevistado 11).

É moderno e clássico ao mesmo tempo. Todos nós, desde a nossa vestimenta, isso é muito bem cuidado, desde o nosso atendimento. No nosso atendimento, é uma coisa mais tranquila, mas mesmo assim a gente está sempre com uma camisa. É um cuidado porque a gente lida com uma coisa diferente, e de alguma forma você sempre vende a imagem. Então, os homens sempre de terno completo, as mulheres com vestido ou um terninho (Entrevistado 14).

Quando nós fomos para o programa do Raul Gil, tinha um estilista lá que quis trocar a roupa da gente lá. Ele queria trocar [...] e o próprio Raulzinho, filho do Raul falou: 'Não mexe com esse cara, porque eles estão perfeitos e isso aí passa credibilidade'. Nós ouvimos isso dele, 'esse visual deles passa credibilidade, deixa eles [serem eles] mesmos, não são garotinhos que vão pôr calça jeans apertada, deixa os caras assim'. Então, esse visual passa credibilidade, é influência deles mesmo, dos Bee Gees. [...] Pesquisa. Eu, por exemplo, tenho a biografia deles toda do Bee Gees, desde a demo que eles fizeram com violão e voz para dar a música para alguém, a gente tem tudo isso (Entrevistado 15).

Eu contratei um técnico de som do Barão Vermelho [...] para ele prestar uma consultoria [...] Olha, a gente quer chegar nesse som, como é que a gente faz? Entendeu? (Entrevistado 12).

[...] foi fluindo, eu até acho que isso é um amadurecimento, que esse é o vestibular do músico, sabe. Quando se vê por esse lado, é um lado maduro, porque a música... o lado estético dela tem que estar na sonoridade. O músico tem que por um headfone na cabeça, deitar na poltrona de trás do carro, fechar os olhos, ouvir o som e ver a banda tocando, sem nenhum vídeo, sem nada na sua frente. Então, a sonoridade traz estética, traz visual, e é isso que nós queremos (Entrevistado 1).

$\mathrm{Na}$ análise das estratégias relacionadas a projetos e planos futuros para a identidade estética das bandas, foram identificadas três tipos de strategizing: (a) quase metade das bandas têm projetos e planos futuros para a identidade estética; (b) bandas sem planejamento futuro preferem manter as atuais estratégias da identidade estética; (c) bandas que têm projetos e planos futuros para identidade estética, mas contudo não possuem recursos financeiros para investimento ou patrocinadores para viabilizar financeiramente tais ações.

Há dois anos atrás a gente convidou uma pessoa que estava afim de fazer essa consultoria, e ela acompanha o grupo até hoje. Então posso dizer que anualmente a gente revisa, mas a gente agora fez um planejamento estratégico que a gente vai voltar meio que é próximo de 2020 que é quando a gente tem nossas metas estabelecidas (Entrevistada 4).

É, já não estamos naquela coisa de ir atrás de... emboscada [...] chegar não sei aonde... para chegar lá com uma caixa queimada (Entrevistado 10).

[...] eu mandei para a Lei de Incentivo Municipal de Araguari para ver se a gente consegue bancar pelo menos 4 meses, porque fica caro e a gente não tem público ainda para esse tipo de música, infelizmente (Entrevistado 7). 
A interação entre os principais atores das bandas musicais é, normalmente, intensa, devido ao fluxo de práticas e decisões que ocorre no dia a dia: longos períodos de ensaios, reuniões, shows, viagens etc. Conforme análise das entrevistas, são comuns o ingresso e a saída de músicos em uma banda no decorrer de uma trajetória artística e musical. Os principais critérios estabelecidos pelas bandas para definirem o ingresso e a permanência de um músico no conjunto musical, bem como as decisões e políticas para a formação e composição das bandas, são: profissionalismo (responsabilidade, disciplina, não ter vícios, compromisso, cumprir regras etc.), trabalho em equipe (relacionamento, interação e convivência etc.), habilidades (qualidade técnica e experiência) e identificação com a banda (gostar do som da banda, alinhamento com o projeto da banda, entrar no esquema da banda).

O critério que mais se destaca é o profissionalismo relacionado com a capacidade do músico para se comprometer com as atividades necessárias ao funcionamento da banda. Também a qualidade técnica que o profissional pode trazer para a banda a partir de sua experiência ou habilidade. Conforme citado nas entrevistas, a falha de um membro da banda pode causar alto impacto no produto final. Quanto ao relacionamento entre os membros de uma banda, a maioria das bandas consideram importante a capacidade de trabalho em grupo e de convivência com os demais membros. Foi identificado um sentido de "família" em uma banda musical, devido às suas rotinas de muitas horas de trabalho juntos, diversas viagens e também um trabalho em que cada músico é importante para o resultado final da entrega. Os entrevistados também citaram como critério para o ingresso na banda a identificação desse músico com o projeto da banda; é importante o músico gostar do estilo musical e das atividades que essa banda exerce e até mesmo se identificar com a forma de pensar e agir da banda.

A análise das entrevistas mostrou que os estrategistas das bandas pesquisadas consideram que as práticas mais citadas como importantes para a trajetória de crescimento e de popularização da banda são as práticas técnicas, sonoras e musicais. Para a maioria das bandas pesquisadas, a qualidade do som, a qualidade técnica e a qualidade dos produtos da banda foram fundamentais para a sobrevivência e a continuidade da banca no mercado. Também os aspectos comportamentais foram citados como parte do strategizing das bandas: profissionalismo, comprometimento, dedicação, persistência e seriedade. Esses fatores, geralmente, são considerados fundamentais para a banda alcançar a qualidade técnica e, por consequência, conquistar mercado, conseguir agenda de shows e reconhecimento do público.

$\mathrm{Na}$ trajetória das bandas pesquisadas, as condições externas geralmente são citadas como importantes para o seu crescimento e a sua popularização. Dentre essas condições têm aquelas específicas da indústria fonográfica, da indústria musical e da indústria cultural: espaço e apoio das gravadoras, apoio e convite para programas de TV, rádio e para shows em locais de grande visibilidade, apoio de artista de renome e influências e apoio na Internet. Os entrevistados também citaram empresas e pessoas que, de alguma forma, contribuíram em momentos específicos e significativos para as bandas musicais. Outras questões citadas que influenciam a trajetória de 
crescimento e de popularização da banda são: interação com fãs, trabalho em equipe entre os músicos, identificação com o estilo musical e com a sonoridade produzida pela banda, assim como planos e expectativas para a carreira do próprio músico.

\begin{abstract}
[...] basicamente, no mercado musical, se tiver que resumir... resumir mesmo é música. O que faz a diferença na carreira de um artista é a música, se ele tem uma música boa, uma música que agrada o pessoal. Só que daí para se tornar um artista nacional, aí já é música e trabalho (Entrevistado 9).

Profissionalismo. Qualidadetécnica, profissionalismo, comprometimento, são fatores básicos, mas muitas vezes não existe, sabe? A maioria das vezes o básico faz uma diferença grande demais. Porque as pessoas tendem... quando surge um desafio ou uma empreitada, nós tendemos a querer ser o que nós não somos para atingir alguma graça, vamos falar assim (Entrevistado 12)

E naquele momento que a gente foi fazer o DVD, a gente estava no programa do Raul Gil, nós ficamos 23 semanas naquele programa, então nós ficamos conhecidos nacionalmente através daquele programa. $E$ assim, você chegava lá, 'os Bee Gees, os Bee Gees', o Brasil inteiro! Aquele negócio, não que a gente queria ficar na sombra, mas já estava rotulado (Entrevistado 15).

A gente faz uma pesquisa, aquele momento que a gente faz uma parada para ouvir rádio, para fazer pesquisa de internet, ver o que está tocando. Porque, às vezes, estamos na estrada, focados no trabalho, mergulhados nas demandas. Às vezes, você não tem uma noção real do que está realmente rolando (Entrevistado 9).
\end{abstract}

Em relação aos planos para o futuro, para metade das bandas pesquisadas, as estratégias futuras de crescimento e popularização emergem no dia a dia, estando presentes fatores como intuição e fluxo de ideias dos principais atores; poucas bandas realizam planejamento estratégico deliberado a partir de uma intenção, de estabelecimento prévio de planos e metas para o futuro da banda. As demais bandas praticam uma estratégia emergente, contudo mais voltada para as atitudes comportamentais dos líderes, principalmente, com ações orientadas para a relação e conquista de fãs e clientes. Uma das bandas pratica o planejamento de longo prazo, deliberado e formal. E, uma outra banda, com práticas situadas nas tradições e cultura locais da região tem sua fonte de receitas direcionada a projetos de captação de recursos financeiros por meio de leis de incentivo ou parcerias com órgãos públicos.

\title{
Conclusões
}

Nesta pesquisa, o strategizing de 11 bandas musicais foi analisado enquanto fluxos de práticas que articulam identidades e estilos. A pesquisa mostrou que o conceito de strategizing, promovido em abordagens pósestruturalistas da estratégia como uma prática social, que compreendem a estratégia como uma prática relacional, performativa e discursiva, dialoga com abordagens dos Estudos Culturais para o estudo das práticas dos estrategistas das bandas musicais. Esse diálogo evidenciou a natureza transversal das práticas que buscam a sobrevivência e o crescimento das bandas de música. Sobretudo, mostrou como essa busca é conduzida por 
artística para a sua banda.

Estudos futuros podem enfatizar os aspectos políticos dessa articulação entre identidades e estilos, com foco nas interações entre bandas e gravadoras, ao papel estratégico e sócio histórico das bandas, que produzem bens comerciais que são também bem culturais e, por vezes, assumem papel relevante no campo político (blues, rock, punk rock, grunge). Estudos futuros também podem buscar outros gêneros musicais que não foram objeto deste estudo. As leituras sobre bandas musicais mostram que determinados gêneros musicais como o sertanejo, por exemplo, tem uma forte influência de fatores como: companhias fonográficas, distribuidoras, escritórios empresariais, mídias televisivas etc. Isso significa que alguns gêneros musicais parecem ser mais suscetíveis à influência do ambiente institucional.

As práticas adotadas pelas bandas estudadas certamente têm especificidades que podem não ser encontradas em bandas que atuam principalmente em âmbito nacional e internacional. O aprofundamento do estudo de determinados gêneros ou o estudo apenas de bandas de grande porte poderia revelar práticas não identificadas na presente pesquisa, a qual adotou como foco bandas com atuação sobretudo regional. Os shows das bandas, por si só, são potenciais fontes de análise de rituais e estratégias emergentes e efêmeras. A pesquisa mostrou que o strategizing das bandas musicais pode se beneficiar de mais estudos no campo da estratégia, especialmente sobre a história de vida dos líderes-estrategistas.

\section{Agradecimentos}

Os autores agradecem ao editor e aos avaliadores da RECADM por suas contribuições para o aprimoramento desse artigo.

\section{Referências}

Albino, J., Gonçalves, C. A., Carrieri, A., \& Muniz, R. M. (2010). Estratégia como prática: uma proposta de síntese. Revista Portuguesa e Brasileira de Gestão, 9(12), 2-14.

Becker, H. (1974). Art as collective action. American Sociological Review, 39(6), 767776. doi:https://doi.org/10.2307/2094151

Benner, M. J., \& Waldfogel, J. (2016). The song remains the same? Technological change and positioning in the recorded music industry. Strategy Science, 1(3),129147. doi: https://doi.org/10.1287/stsc.2016.0012

Born, G. (2011). Music and the materialization of identities. Journal of Material Culture, 16(4), 376-388. doi: https://doi.org/10.1177/1359183511424196

Bourdieu, P. (2013). A distinção. Porto Alegre: Zouk.

Blacking, J. (2007). Música, cultura e experiência. Cadernos de Campo, São Paulo, 16(16), 201-218. doi: https://doi.org/10.11606/issn.2316-9133.v16i16p201-218 
Brown, S. C. (2014). 'With a little help from my friends': peer production and the changing face of the live album. International Journal of Music Business Research, 3(1), 52-66.

Burgelman, R. A., Floyd, S. W., Laamanen, T., Mantere, S., Vaara, E., \& Whittington, R. (2018). Strategy processes and practices: Dialogues and intersections. Strategic Management Journal, 39(3), 531-558. doi:https://doi.org/10.1002/smj.2741

Carter, C., Clegg, S. R., \& Kornberger, M. (2008). Strategy as practice? Strategic Organization, 6(1), 83-99. doi: https://doi.org/10.1177/1476127007087154

Chia, R. \& Mackay, B. (2007). Post Processual Challenges for the Emerging Strategy-as-Practice Perspective. Human Relations, 60(1), 217-242. doi: https://doi. org/10.1177/0018726707075291

Cohen, S. (1991). Rock culture in Liverpool: popular music in the making. Oxford: Clarendon/ Oxford Univ. Press.

Davidson, J.W, \& Good, M. M. J. (2002). Social and musical co-ordination between members of a string quartet: an exploratory study. Psychology of Music, 30(2), 186201. doi: https://doi.org/10.1177/0305735602302005

Denis, J. L., Langley, A., \& Rouleau, L. (2007). Strategizing in pluralistic contexts: rethinking theoretical frames. Human Relations, 60(1), 179-215. doi: https://doi. org/10.1177/0018726707075288

Denzin, N. K., \& Lincoln, Y.S. (2006). Introdução: a disciplina e a prática da pesquisa qualitativa. In N. K. Denzin, \& Y. S. Lincoln (Orgs.). O planejamento da pesquisa qualitativa (pp. 15-42). Porto Alegre: Artmed.

Erlewine, S. T. (2014). Biography Ramones. Recuperado em 10 julho, 2014, de http://www.billboard.com/artist/359662/ramones/biography

Ezzamel, M., \& Willmott, H. (2010). Strategy and strategizing: a poststructuralist perspective. In J. A. C. Baum \& J. Lampel (Eds.). The globalization of strategy research. Advances in strategic management (Vol. 27, pp. 75-109). Bingley, UK: Emerald.

Featherstone, M. (1995). Cultura de Consumo e Pós-modernismo. São Paulo: Studio Nobel.

Flick, U. (2009). Introdução à pesquisa qualitativa. Porto Alegre: Artmed.

Frith, S. (1987). Towards an aesthetic of popular music. In R. Leppert, \& S. McClary (Orgs.). Music and society (pp. 133-149). Cambridge: Cambridge University Press.

Frith, S. (1996). Music and identity. In S. Hall e P. Du Gay. Questions of cultural identity (pp.108-127). London, UK: Sage Publications.

Gaskell, G. (2010). Entrevistas individuais e grupais. In M. W. Bauer, \& G. Gaskell (Orgs.). Pesquisa qualitativa com texto, imagem e som (pp. 64-89). Petrópolis: Vozes.

Golsorkhi, D., Rouleau, L., Seidl, D., \& Vaara, E. (2010). Cambridge Handbook of Strategy as Practice. Cambridge: Cambridge University Press.

Gomes, R. (2007). Calypso e Zeze di Camargo são os mais ouvidos no Brasil, diz Datafolha. Recuperado em 10 julho, 2015 de Jornal Folha de S. Paulo, de http:// www1.folha.uol.com.br/ilustrada/2007/07/314097-calypso-e-zeze-di-camargosao-os-mais-ouvidos-no-brasil-diz-datafolha.shtml. 
Hall. S. (2000). Quem precisa da identidade? In T. T. Silva (Org.), S. Hall, \& K. Woodward. Identidade e diferença (pp. 103-133). Petrópolis, RJ: Vozes.

Hall. S. (2016). Cultura e representação. Rio de Janeiro: Ed. PUC-Rio: Apicuri.

Harper, D. (1994). On the authority of the image: visual methods at the crossroads. In Y. S. Lincoln \& N. K. Denzin (Orgs.). Handbook of qualitative research (p. 403-413). Thousand Oaks, California: Sage Publication.

Hesmondhalgh, D. (2005). Subcultures, scenes or tribes? None of the above. Journal of Youth Studies, 8(1), 21-40. doi: https://doi.org/10.1080/13676260500063652

Janotti Jr., J. (2006). Música popular massiva e gêneros musicais: produção e consumo da canção na mídia. CMC: Comunicação, Mídia e Consumo, São Paulo, 3(7), 31-47.doi: http://dx.doi.org/10.18568/cmc.v3i7.69

Jarzabkowski, P., Balogun, J., \& Seidl, D. (2007). Strategizing: the challenges of a practice perspective. Human Relations, 60(1), 5-27. doi: https://doi. org/10.1177/0018726707075703

Jarzabkowski, P., \& Spee, P. (2009). Strategy-as-practice: a review and future directions for the field. International Journal of Management Reviews, 11(1), 69-95. doi: https://doi.org/10.1111/j.1468-2370.2008.00250.x

Jarzabkowski, P., \& Whittington, R. (2008). A strategy-as-practice approach to strategy research and education. Journal of Management Inquiry, 17(4), 282- 286. doi: $7 / 1056492608318150$

Johnson, G., Melin, L., \& Whittington, R. (2003). Micro-strategy and strategizing: towards an activity-based view. Journal of Management Studies, 4O(1), 3-22. doi: https://doi.org/10.1111/1467-6486.t01-2-00002

Kelly, D. (2007). The beautiful and the damned. Recuperado em 20 agosto, 2015 de The Guardian, https://www.theguardian.com/theobserver/2007/jan/28/music

Kornberger, M., \& Clegg, S. (2011). Strategy as performative practice: The case of Sidney 2030. Strategic Organization, 9(2), 136-162. doi: https://doi. org/10.1177/1476127011407758

Lemos, R., \& Castro, O. (2008). Tecnobrega. Rio de Janeiro: Aeroplano.

Maitlis, S., \& Lawrence. T. B. (2003). Orchestral manoeuvres in the dark: understanding failure in organizational strategizing. Jornal of Management Studies, 4O(1), 109-139. doi: https://doi.org/10.1111/1467-6486.t01-2-00006

Melnick, M. A. \& Meyer, F. (2013). Na estrada com os Ramones. São Paulo: Edições Ideal.

Mirabeau, L., Maguire, S., \& Hardy, C. (2018). Bridging practice and process research to study transient manifestations of strategy. Strategic Management Journal, 39(3), 582-605. doi: https://doi.org/10.1002/smj.2732

Murnighan, J. K., \& Conlon, D. E. (1991). The dynamics of intense work groups: a study of British string quartets. Administrative Science Quarterly, 36(2), 165-186. doi: https://doi.org/10.2307/2393352

Nakano, D. (2010). A produção independente e a desverticalização da cadeia produtiva da música. Gestão e Produção, 17(3), 627-638. doi:https://doi.org/10.1590/S0104530X2010000300015

Penn, G. (2010). Análise semiótica de imagens paradas. In M. W. Bauer, \& G. Gaskell. Pesquisa Qualitativa com texto, imagem e som (pp. 319-342). Petróplis, RJ: Vozes. 
Pereira, S. L., \& Pontes, V. (2017). Culturas juvenis, identidades e estilo de vida: sentidos do "alternative" no Baixo Augusta/São Paulo. CMC: Comunicação, Mídia e Consumo, 14(40), 111-130. doi:https://doi.org/10.18568/cmc.v14i40.1300

Peterson, R. A., \& Kern, R. M. (1996) Changing highbrow taste from snob to omnivore. American Sociological Review, 61(5), 900-907. doi: https://doi.org/10.2307/2096460

Regnér, P. (2008). Strategy-as-practice and dynamics capabilities: steps towards a dynamics view of strategy. Human Relations, 61(4), 565-588. doi:https://doi. org/10.1177/0018726708091020

Rouleau, L. (2013). Strategy-as-practice research at a crossroads. M@n@gement, 16(5), 547-565. doi:https://doi.org/10.3917/mana.165.0574

Salazar, L. (2010). Música Ltda. Recife: Sebrae.

Samra-Fredericks, D. (2003). Strategizing as lived experience and strategists' everyday efforts to shape strategic direction. Journal of Management Studies, 4O(1), 141-174. doi: https://doi.org/10.1111/1467-6486.t01-1-00007

Shuker, R. (1999). Key concepts in popular music. Londres: Routledge.

Straw, W. (2006). Scenes and sensibilities. E-compós, 6(1), 1-16. doi:https://doi. org/10.30962/ec.v6i0.83

UNCTAD (2010). United Nations Conference on Trade and Development. Creative Economy Report 2010. Genebra: UNCTAD/ DITC. Recuperado em 08 junho, 2014, de http://www.unctad.org/en/docs/ditctab20103_en.pdf.

Vaara, E., \& Whittington, R. (2012). Strategy-as-practice: taking social practices seriously. Academy of Management Annals, 6(1), 285-336. doi: https://doi.org/10.1 080/19416520.2012.672039

Vila, P. (2012). Práticas musicais e identificações sociais. Significação, 39(38), 247-277. doi: https://doi.org/10.11606/issn.2316-7114.sig.2012.71197

Whittington, R. (2003). The work of strategizing and organizing: for a practice perspective. Strategic Organization, 1(1), 117-125. doi: https://doi. org/10.1177/147612700311006

Whittington, R., \& Melin, L. (2003). The Challenge of organizing/strategizing. In A. Pittigrew et al. (Eds) Innovative forms of organizing (pp. 35-48). London: Sage Publications.

Whittington, R., Molloy, E., Mayer, M., \& Smith, A. (2006). Practices of Strategising/ organizing: broadening strategy work and skills. Long Range Planning, 39(6), 615-629. doi: https://doi.org/10.1016/j.lrp.2006.10.004

Wilson, D. C., \& Jarzabkowski, P. (2004). Thinking and acting strategically: new challenges for interrogating strategy. European Management Review, 1(1), 14-20. doi: https://doi.org/10.1057/palgrave.emr.1500008

Woodward, K. (2000). Identidade e diferença: uma introdução teórica e conceitual. In T. T. Silva (Org.), S. Hall, \& K. Woodward. Identidade e diferença (pp. 7-72). Petrópolis, RJ: Vozes.

Yin, R. K. (2005). Estudo de caso. Porto Alegre: Bookman. 